\title{
Research on the Application of PAD Class Mode in Vocational English Teaching Based on Duifene Platform
}

\author{
Yan Li, Xiaoqing Wen, Xianjiu Liao* \\ Youjiang Medical University for Nationalities, Baise, China \\ Email: *lxj2006910@163.com
}

How to cite this paper: Li, Y., Wen, X. Q., \& Liao, X. J. (2021). Research on the Application of PAD Class Mode in Vocational English Teaching Based on Duifene Platform. Advances in Applied Sociology, 11, 335-339.

https://doi.org/10.4236/aasoci.2021.117030

Received: June 18, 2021

Accepted: July 20, 2021

Published: July 23, 2021

Copyright $\odot 2021$ by author(s) and Scientific Research Publishing Inc. This work is licensed under the Creative Commons Attribution International License (CC BY 4.0).

http://creativecommons.org/licenses/by/4.0/

\begin{abstract}
Responding to the call of the times for education and teaching reform, the PAD Class fully exerts the advantages of "Internet + Education" and exemplifies the "student-centered" education idea. The PAD Class consists of three explicit learning links: presentation, assimilation, and discussion, which gives a full play to the strengths of teachers, and follows students' learning rules to help students learn and master knowledge efficiently. Duifene Platform, the official teaching platform of PAD Class, enables teachers to deal with meticulous and tedious teaching tasks in an easy, happy and efficient way. It is a new and universal teaching platform. PAD Class and Duifene Platform complement and reinforce each other.
\end{abstract}

\section{Keywords}

Duifene Platform, PAD Class Mode, Vocational English Teaching

\section{Introduction}

The Internet + Education Action Plan (2018-2022) released in Guangxi in 2019, clearly stated that a new student-centered educational ecology concept will be built both online and offline by adhering to the deep integration of information technology and education and teaching. Students' learning abilities and habits of flexible utilization of network information technology can be developed by means of the "Internet + Education" platform. Everyone can learn whenever and wherever they want. Students will be encouraged to remain lifelong study by learning in a proactive, self-directed and cooperative manner.

In 2014, Professor Zhang Xuexin, the Dean of the Psychology School of Fudan University, proposed a new and original teaching mode-PAD Class. The teaching 
mode responds to the call of the new era for education and teaching reform, and brings new inspiration and enlightenment for the education and teaching reform of universities and colleges in remote ethnic minority areas. For PAD Class, teachers give a presentation in half of the classroom time, and left remaining time for students to carry on the discussion-based interactive learning. There is a-week interval between the two classes, during which students are allowed to assimilate knowledge independently. PAD Class clearly divides a learning process into three parts: presentation, assimilation and discussion (Zhang, 2014).

Duifene Platform, the official teaching platform of PAD Class (Liu \& Yu, 2021), includes attendance, curriculum resources, students, online exercises, classroom questions, homework, WeChat messages, discussion forums, questionnaires, etc. With its novelty and universality, it helps teachers deal with meticulous and tedious teaching tasks in an easy, happy and efficient way.

\section{Implementation of PAD Class Mode in Vocational English Teaching Based on Duifene Platform}

\subsection{Teaching Arrangement}

The research is targeted on non-English major vocational students enrolled in 2020. Take Section A Wealth, Success or Love as an example, which is derived from Unit 3 Learn a Lesson from Universal Stories of New Horizon College English - Reading and Writing (3rd Edition) 1, published by FLTRP (Foreign Language Teaching and Research Press). The unit is set to 4 class hours for 2 classes, with 2 hours each. The PAD Class of this course has two parts, i.e. presentation in the first class and discussion in the second class. There is a week between the two classes left for students to assimilate independently.

\subsection{Presentation}

Students' class attendance can be checked through the WeChat official account of Duifene Platform, which can both supervise students' timely attendance efficiently and conveniently and remind students to concentrate on and prepare for classes. As the most attractive link in traditional teaching, lead-in teaching is reserved in PAD Class to activate classroom atmosphere and enthuse students in learning. In this unit, teachers prepare their favorite stories carefully, leading in the topic by means of videos, audios, pictures and texts to broaden students' vision and knowledge and impart norms of human behaviors to them. Teachers' sharing will lead the way for students and provide them a reference and example. After the lead-in, teachers analyze the article structure to help students clear their mind on the author's writing ideas and framework, themes and values.

\subsection{Assimilation}

During the assimilation, teachers integrate relevant teaching resources and send them to students through the section of curriculum resources on the Duifene Platform. After a difficult and arduous start, teachers will feel better as materials 
are increasingly accumulated through teamwork and cooperation of every two teachers on one unit. Students should assimilate the knowledge in the following aspects: 1) Prepare their favorite story and illustrate their inspiration and feelings; 2) Read and memorize related words; 3) Read the text fluently and mark the puzzling words and sentences. Learn independently by leveraging books, networks and the resources provided by teachers on the Duifene Platform.

Students should prepare their favorite stories first. In the preparation process, they should apply the accumulated knowledge to practice comprehensively and learn from practice. While puzzling words and sentences are unavoidable, the abundant network information will facilitate student in learning. Then read and memorize words. We use New Horizon College English - Reading and Writing ( $3 r d$ Edition), provided with UNIPUS App, as the textbook of this course to help students in listening training, word spelling and memory anytime and anywhere. Finally, read the text aloud. Students may read aloud with the App, take notes on the puzzling words and sentences, inquire and solve problems independently by recurring to network resources or ask classmates and teachers for help by the "Help Me" section on the Duifene Platform. In the process of discussion and tackling problems, students may both strengthen their knowledge and develop their abilities of writing, expression and logical thinking.

\subsection{Discussion}

As for the input stage of assimilation, discussion, a student-centered interactive output link allows students to enjoy the power and pleasure brought by knowledge through sharing. Students can group themselves on their free will, or can be divided into groups quickly by using the random grouping function of Duifene. Through speaking in groups, their oral expression ability, courage and confidence get improved. After the group discussion, representatives of each group are required to make a summary speech, and other groups will make a supplement, thus to cultivate their innovative and critical thinking ability and develop their analytical skills. Reading and spelling of words and texts are conducted in groups as well. English subject integrates listening, speaking, reading, writing and translation. Vocabulary accumulation provides a solid base for steady development of all the five skills. Members help each other in word dictation and recitation, and high-achieving students will supervise and urge other members to learn. Most vocational students are weak in English and afraid of speaking English. By reading aloud the text in the group, they may develop language intuition and accumulate materials to lay a solid foundation for English learning.

\section{Effect of PAD Class Mode in Vocational English Teaching Based on Duifene Platform}

\subsection{Change the Teaching Mode of Infusion}

In traditional teaching, teachers play the roles of leaders and instructors of knowledge. Studies show that it is a passive learning process for students, and 
the available information provided by teachers is limited. They just memorize the most of what they learned without further reprocessing, organization and assimilation, and will soon forget. However, the process of the student-centered PAD Class teaching includes: assimilation, deep processing and learning, discussion, re-expression, knowledge refining, and expressing in their own way. Students will master more knowledge and greatly improve their learning efficiency (Ding, 2018).

\subsection{Improve the Quality of Classroom Interaction}

In traditional English teaching, most teachers are more likely to raise simple questions when interacting with students. In this case, students may answer questions in English without adequate preparation. The assimilation of PAD Class enables students to have a comprehensive, systematic and in-depth study and understanding of topics and values of the article. Then they can have a deep interaction with teachers regarding questions, and get a state of in-depth learning. By after-class communication, we learn about that students are not able to collect materials and make sentences in short time rather than unwilling to interact with teacher in traditional classes, or they have trouble in raising questions due to lack of in-depth learning, and thus result in hardly having interesting interactions with teachers.

\subsection{Improve Learning Efficiency}

We developed a questionnaire via Duifene Platform after class, and found that about $90 \%$ of students believed that PAD Class improved their learning efficiency. Students will find it is novel and interesting to learn the new knowledge when it comes to presentation. In the period of assimilation, discussion will be carried out in groups. College students, under the pressure of members, prefer to behave better, thus to be recognized and praised by others, so most students are willing to take more time for independent learning. With adequate preparation, they may make every speech confidently during the discussion, thus creating a virtuous circle of learning and their learning confidence can be enhanced. All parts, from teaching, assimilation to discussion, are very tight and efficient. Students are inspired to learn, and find, analyze and solve problems. Therefore, it may be concluded that the PAD Class is an efficient mode based on brain science (Zhang, 2019).

\section{Conclusion}

PAD Class can maximize students' potential in learning, and cultivate their good learning habits of flexible utilization of network information technology, to better implement the "Internet + Education" education mode. Though students may find heavier learning tasks than in traditional classes, they enjoy the tired and happy process. Whenever they learn, they can gain knowledge and happiness as well as enhancement of their self-efficacy in learning. This paper is in- 
tended to encourage more educational practitioners who are still thinking and taking a wait-and-see attitude to try to apply the PAD Class mode and have a magic experience in PAD Class.

\section{Fund Program}

2018 Guangxi Vocational Education Teaching Reform Research Project $+R e-$ search and Practice of PAD Class based on WeChat Platform in Higher Vocational Public English Teaching in Minority Areas + (GXGZJG2018B161).

\section{Conflicts of Interest}

The authors declare no conflicts of interest regarding the publication of this paper.

\section{References}

Ding, X. N. (2018). Learning Adaptability Study of PAD Class in University Course Teaching. Chongqing Higher Education Research, 6, 106-117.

Liu, G. X., \& Yu, Z. Y. (2021). On the Half-Half Class Practice of Information Technology Teaching in University Classroom. The Theory and Practice of Innovation and Entrepreneurship, 4, 41-43+46.

Zhang, X. X. (2019). PAD Class Mode Leads to New and Efficient Classroom. Yunnan Education (Vision and Politics), No. 5, 41-42.

Zhang, X. X. (2014). PAD Class: A New Attempt in University Teaching Reform. Fudan Education Forum, 12, 5-10. 